
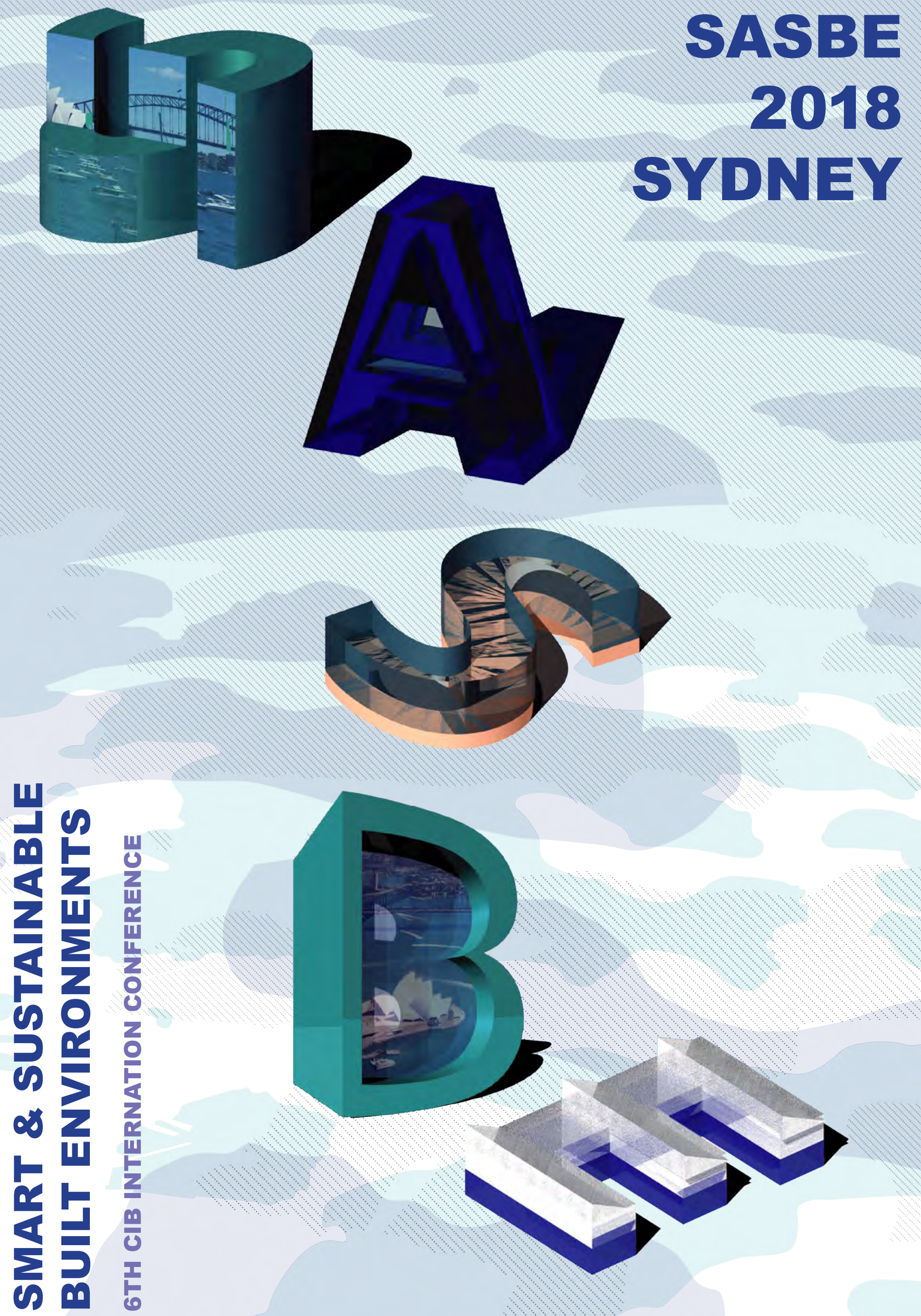


\section{PRODUCING WORK-READY GRADUATE FOR THE CONSTRUCTION INDUSTRY}

Sadegh Aliakbarlou ${ }^{1 *}$, Suzanne Wilkinson², Seosamh B. Costello², Hyounseung Jang ${ }^{3}$, Hamid Aliakbarlou ${ }^{4}$

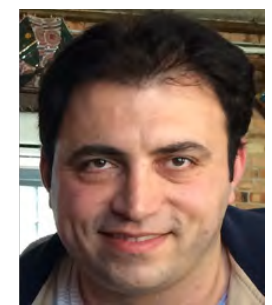

1 Departement of Building and Construction Services, Unitec, New Zealand, saliakbarlou@ unitec.ac.nz

2 Department of Civil and Environmental Engineering, University of Auckland, New Zealand, s.wilkinson@auckland.ac.nz; s.costello@auckland.ac.nz

3 School of Architecture, Seoul National University of Science \& Technology, Korea, jang@ seoultech.ac.kr

4 Department of Civil Engineering, Amirkabir University of Technology, Tehran, 145888, Iran, hamidaliakbarloo@gmail.com

\section{Summary}

While educating building professionals is an essential component of the construction education sector, producing work-ready graduates to meet the construction industry requires greater effort. The factors that influence graduate students' successful transition into the competitive construction environment need to be further explored. This study investigates these factors through a literature review and interviews six experts in academia who have industry experience. The findings of this study show that factors such as 'team-working skills' and 'communication skills' are the two top factors for producing work ready graduates for the construction industry. The findings can help academia to understand the important factors for producing work-ready graduates for the construction industry.

Keywords: construction, employability, work-ready graduates 


\section{Introduction}

Graduate employability depends on the quality of education. As defined by Brynteson (2012), employability is about skills that can help graduates to find proper employment, in accordance with their experiences and knowledge. Carroll (2011) stated that employability of graduates can be considered as a remarkable benchmark to measure the quality of higher education.

Achieving excellent graduate results depends on producing employable graduates. This is due to the fact that individuals select their tertiary education in order to achieve the skills they need for a rewarding work life. They select what to study because of "what they are capable of and what will get them started on a career" (New Zealand Ministry of Education, 2013). Hence, educational service providers are required by the governments to improve the employability agenda across their organisations, and many of them have attempted to meet this challenge, with varying degrees of success (Culkin \& Mallick, 2011).

The response by the educational service providers is not sufficient, as there is a need for a more radical approach that can help in empowering new graduates with the knowledge and skills required for setting up a business rather than focusing on simply 'getting a job' (Culkin \& Mallick, 2011). Similarly, Herrmann et al. (2008) stated that graduates, in addition to achieving work skills, are required to develop skills that help them to take risks and opportunities, work flexibly, handle complexity, and achieve team-work skills and awareness.

This paper is structured as follows: first, the significance of this study is presented by reviewing the available literature. Next, key success factors for producing work ready graduates, as the basis for conducting a qualitative study, are identified. Following this, the qualitative findings of this study are presented and they are also compared with the literature findings. Finally, the study's limitations and suggestions for future research are presented.

\section{Significance of the study}

A report by Lambert (2003) provides the UK employer's perspective on the skills market that educational service providers need to consider in their education curricula. This view was revised and supported by the Confederation of British Industry (2009), which developed Figures 1 and 2 to show the role and responsibility that universities need to consider in providing employability skills. As can be seen from the both figures, educational services providers have a significant responsibility for helping students to achieve employability skills.

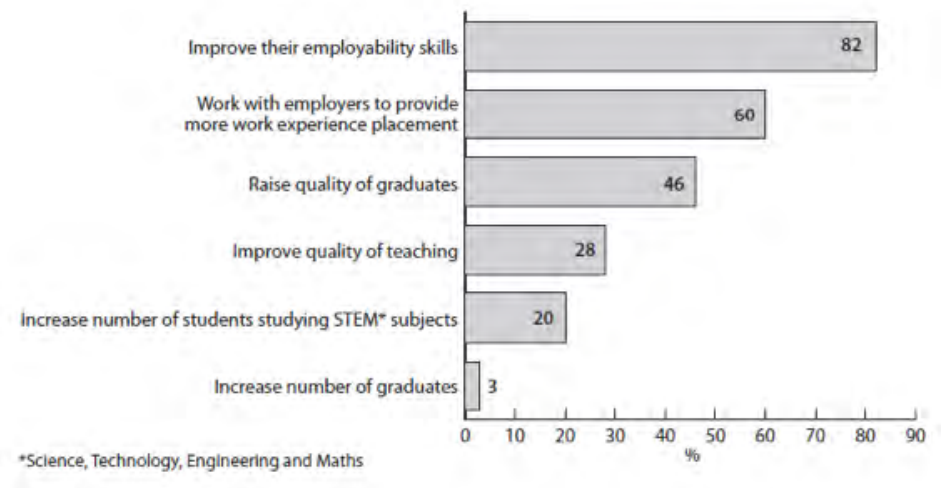

Figure 1 Universities priorities in terms of undergraduates (Source: Confederation of British Industry, 2009) 


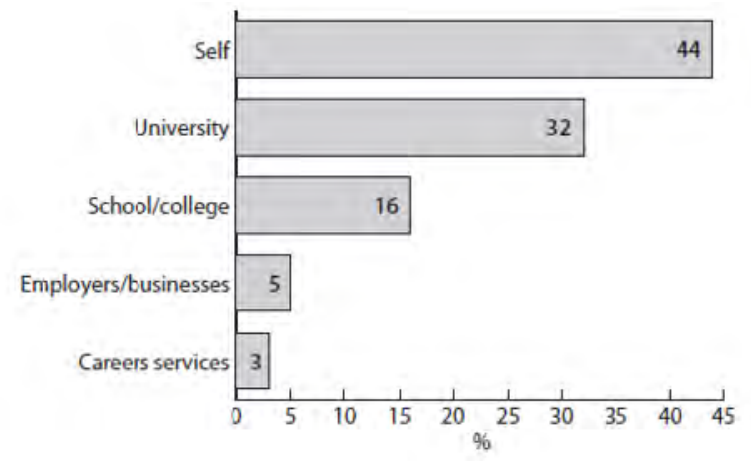

Figure 2 Responsibility for helping students to achieve employability skills. (Source: Confederation of British Industry, 2009)

\subsection{The economic aspects of graduates' employability skills}

Universities in New Zealand are large scale institutions which form an important backbone to the country's economy. For example, they employ around 20,000 full-time staff, have a turnover of more than a $\$ 3.8$ billion annually, and they spend about $\$ 960$ million on research. They teach around 174,000 at any time and graduate around 43,000 students per year (Universities New Zealand, 2018).

New Zealand universities are not only a growth driver for the New Zealand economy, they also play key roles within the construction industry in the country. The New Zealand construction industry is a small but competitive construction market and very important for the overall economy of the country (Construction Strategy Group, 2015). For example, it contributed $8 \%$ to GDP and employed 10\% of the workforce in 2015 (PWC, 2016). Despite the importance of the construction sector for New Zealand, its performance is still low in comparison with some other comparable sectors of the New Zealand economy (PWC, 2016), and other similar economies and countries (Constructing Excellence, 2009). According to Building and Economics Research Limited (2003), a 10\% improvement in New Zealand construction performance would increase the country's GDP by about $\$ 2$ billion. To help achieve this, producing work ready graduates can be considered as an effective approach. Hence, the responsibility for the employability of graduates has been imposed on the government's respective higher education systems. This is aligned with the Theory of Human Capital introduced by Becker (1975), which states that governments are responsible for improving the stock of human capital, as an essential factor for achieving success and performance of knowledge based economies.

Exploring the earnings of graduates helps in understanding the contribution that the tertiary education system is making towards producing work ready graduates. The key findings of a report by the New Zealand Ministry of Education (2013) entitled "looking at the employment outcomes of tertiary education" shows that: "earnings increase with the level of qualification completed; employment rates increase with the level of qualification gained; very few young people who complete a qualification at diploma level or above are on a benefit in the first five years after study; earnings vary considerably by field of study; some qualification types and some fields are associated with high rates of further study; and graduate certificate and diploma graduates have very high employment rates".

\section{Key success factors for producing work ready graduates}

A study entitled 'employers' perceptions of graduate employability' by Eurobarometer (2010) provides insights into the needs of graduate recruiters by assessing the perceptions of employers. In conducting the study, 11 factors such as team-working skills, sector-specific skills, communication skills, computer skills, ability to adapt to and act in new situations, good reading/ 
writing skills, analytical and problem-solving skills, planning and organisational skills, decisionmaking skills, good with numbers, and foreign language skills were considered as key success factors for producing work ready graduates. These factors can be determined as instrumental factors which can be considered as a means to an end (Aliakbarlou et al., 2017b), where the end is about achieving a high level of graduate employability. Based on these 11 factors, this paper reports a pilot study which applies the expert interviews method to prioritise the key success factors for producing work ready graduates in New Zealand.

\section{Research methodology}

This study takes a social constructionist stance where a reality is constructed by individuals activities (Aliakbarlou et al., 2017a). A qualitative research methodology, as used in this study, suggests an in-depth approach to exploring experts' insights about a research question (Aliakbarlou et al., 2018; Mbachu \& Nkado, 2004). In the first step, a literature review was conducted to define the main factors affecting students' employability, as well as to develop a basis to prioritise the key success factors from the identified factors based on New Zealand experts' perspectives. In the second step, by focussing on educational organisations as detailed in Table 1, it was decided to conduct expert interviews with individuals who are experts in the particular field that is being researched (Sugar \& Schwen, 1995). Hence, selection of the research participants from the educational organisations (10 interviewees)' was based on their experience in a university, institute of technology and polytechnic as well as their construction industry experience. Initially, ten organisations were contacted using the researcher's own connections. However, due to, individual availability within the research time frame, six interviewees from five organisations participated in interviews. Selection of the interviewees was based on their knowledge and experience in construction management in New Zealand, Australia and Iran. Table 2 represents the interview participants' details. As Table 2 shows, the participants were senior within their organisations. This helped them to understand what value meant to them from an organisational perspective (Aliakbarlou et al., 2017c). In addition, they had extensive experience and clear ideas about construction employers' recruiting preferences as they had played various roles in construction projects.

Table 1 Organisations' Description

\begin{tabular}{cll} 
Code & \multicolumn{1}{c}{ Educational Organisation Type } & \multicolumn{1}{c}{ Country } \\
\hline P1 & Public - Institute of technology and polytechnics & New Zealand \\
\hline P2 & Private - Institute of technology and polytechnics & New Zealand \\
\hline P3 & Private - University & New Zealand \\
\hline P4-P5 & Private - University & Australia \\
\hline P6 & Public - University & Iran
\end{tabular}

Table 2 Interview Participants' Profiles

\begin{tabular}{ccc} 
Field of expertise & Code & Years of experience \\
\hline \multirow{3}{*}{$\begin{array}{c}\text { Construction industry } \\
\text { experience }\end{array}$} & P1 & 30 \\
\cline { 2 - 3 } & P2 & 10 \\
\cline { 2 - 3 } & P3 & 10 \\
\cline { 2 - 3 } & P4 & 8 \\
\hline & P5 & 20 \\
\hline
\end{tabular}




\begin{tabular}{lll}
\hline & P1 & 10 \\
\cline { 2 - 3 } Educational experience & P2 & 20 \\
\cline { 2 - 3 } & P3 & 20 \\
\cline { 2 - 3 } & P4 & 15 \\
\cline { 2 - 3 } & P5 & 10 \\
\cline { 2 - 3 } & P6 & 10
\end{tabular}

\subsection{Types of questions and structure to address the objectives of the research}

The participants were briefed on the research objectives. In so doing, the list of 11 identified factors (as outlined in Table 3) were explained to the participants. They were then asked to prioritise the 11 factors by assigning a range of scores from 1 to 11 to each factor. This method was selected because the data was collected by conducting interviews that allowed appropriate time for the participants to review the factors and to rank them. The interviews helped to achieve insights into participants' experiences (Aliakbarlou et al., 2017d). By conducting the interviews in this study some underlying contextual information was gained regarding graduate employability. Although the number of interviewees was limited, the interviewees were expert in education. Also, the sample of interviewees represents a range of experts with considerable expertise in construction projects. Conducting interviews with experts in their particular field of expertise is recognised as an appropriate method to justify a research finding (Egbelakin et al., 2015). After obtaining the scores for each factor, by calculating the average for the scores given to each factor, the ranks, as shown in Table 3, have been developed based on the average score for each factor.

In addition, the participants were asked to provide explanations as to how the employers perceive value from each of the 11 factors. However, this paper only represents the identified ranks for the factors.

\section{Findings}

A study by Ray et al. (2012), indicated that there is a significant skills gap between graduates and entry-level requirements. "There is an issue with education systems that fail to produce future workers with the kinds of skills required by today's organisations - let alone those of tomorrow" (Ray et al., 2012). In what follows, the key success factors for producing work ready graduates are addressed.

\subsection{Prioritising key success factors for producing work ready graduates}

Table 3 lists the key success factors in rank order, as determined by this study. Reviewing the interview results (with 3 experts from New Zealand), factors such as 'team-working skills', 'communication skills', and 'good reading/writing skills' were shown to be the 3 most important factors for producing work ready graduates for the New Zealand construction industry. Similarly, these 3 factors were recognised as the 3 most important factors by the Australian experts in this study.

The participant from Iran selected 'team-working skills', 'communication skills' and 'computer skills' as the 3 most important factors. 
Table 3 Factors influencing graduates' successful transition into construction market

\begin{tabular}{|c|c|c|}
\hline Factors & Rank (this study) & Rank (Europe) \\
\hline Team-working skills & 1 & 1 \\
\hline Sector-specific skills & 6 & 2 \\
\hline Communication skills & 2 & 3 \\
\hline Computer skills & 5 & 4 \\
\hline Ability to adapt to and act in new situations & 4 & 5 \\
\hline Good reading/writing skills & 3 & 6 \\
\hline Analytical and problem-solving skills & 7 & 7 \\
\hline Planning and organisational skills & 11 & 8 \\
\hline Decision-making skills & 10 & 9 \\
\hline Good with numbers & 9 & 10 \\
\hline Foreign language skills & 8 & 11 \\
\hline
\end{tabular}

\subsection{Comparison between studies}

Table 3 shows how the perception of graduate employability in Europe differs from the participants of this study.

\section{Similarities between studies}

Team-working skills and communication skills were identified among the most important factors by both studies. 'Team-working skills' was ranked first by both studies. 'Communication skills' was ranked third and second by the European and this study's participants, respectively. In addition, 'computer skills' and 'ability to adapt to and act in new situations' were regarded as important factors by both sets of respondents, since they were ranked (fourth and fifth) and (fifth and fourth) by European and this study's participants, respectively. 'Analytical and problemsolving skills' was ranked seventh by both sets of respondents. Finally, 'decision-making skills' and 'good with numbers' were ranked (ninth and tenth) and (tenth and ninth) by European and this study's participants, respectively.

\section{Differences between studies}

'Sector-specific skills' was ranked as the second most important factor by the European participants while it was ranked sixth in this study. Also, 'planning and organisational skills' was ranked as the eighth most important factor by the European participants while it was ranked as the eleventh most important factor in this study.

Finally, while communication skills are ranked highly important for both sets of respondents, there is not strong agreement among them regarding 'good reading/writing skills' as well as 'foreign language skills'. 'Good reading/writing skills' and 'foreign language skills' were ranked (sixth and eleventh) and (third and eighth) by European and this study's participants, respectively.

\subsection{Implications of the findings}

The study's findings help in better understanding the factors that influence graduates' successful transition into the construction industry. While the findings highlighted factors necessary to achieve successful results for the students and educational services providers, they can also help employers to recruit new graduates who have the skills and knowledge that their organisations 
need to succeed (Finch et al., 2013). This is also critical for the growth of the constructing industry which is a knowledge-based economy.

Developing an educational strategy that recognises, prioritises and satisfactorily delivers these factors is essential to ensure that the highest levels of student employability are achieved. For example, as 'team-working skills' and 'communication skills' are the two key factors for producing work ready graduates, promoting collaborative learning cultures gains importance. However, individual assignments and activities are preferred to team assignments and activities by students (Raidal \& Volet, 2009), due to, for example, poorly designed assignments and activities with lack of support from the their supervisor, unequal same contributions from team members working on the same assignment, and lack of having an appropriate space (classroom) to conduct a meeting and group activities (Scager et al., 2016). To help this improve, using a collaborative space (instead of a traditional classroom) and a team project task that lends itself to both collaboration and distinct contributions of students is required. This helps students to develop the capabilities and attitudes that are required for their employers. For example, in addition to the two aforementioned factors, achieving 'higher-level reasoning skills', 'accurate and creative problem solving skills', 'willingness to take on difficult tasks', 'intrinsic motivation', and 'ability to transfer learning from one situation to another' are some other key benefits of collaborative learning for students (Johnson et al., 2014), which highlights the significance of collaborative learning for the employability of students (Hayward \& Horvath, 2000).

\section{Conclusion and Further Research}

This study considers employers' views of the factors that are important for employability of graduates. Based on the qualitative findings of this study, 11 employability factors were prioritised based on employers' perspectives. The findings contribute to the existing literature on employability of new graduates. In addition, the study examined how employers' perspectives on significance of the identified factors differ between European's employers and this study's participants.

The findings of this study show that factors such as 'team-working skills' and 'communication skills' are the two most important factors for producing work ready graduates for the New Zealand construction industry. The findings can be used to improve the employability of new graduates, and can be considered by educational services providers when reflecting on employers' recruiting preferences.

By understanding the significance that employers place on key factors for achieving graduate employability, educational service providers can develop curricula based on the development and improvement of important skills that employers look for. Also, it helps graduates to position themselves in the marketplace by highlighting the required factors when they are applying for rewarding work.

An important limitation is related to the scope of the study. The identification of the key success factors for producing work ready graduates in this study is limited, based on the findings of literature and expert interviews. Although the literature review drew on a recognised international source, further interviews and surveys may find that other factors should be added to the list of the factors developed in this study. In addition, this study's findings are subject to the limitations of interview based research. Also, the number of interviewees is small and may not be representative of the views of the wider industry.

Conducting a similar study in other countries is recommended, to determine the adaptability and replicability of the research results in other contexts. Future studies may also identify measurements and benchmarks for the factors in this study. In so doing, the identified factors (and their measurements) can be categorised under 'absolute measures' and 'relative measures' or 'objective measures' and 'subjective measures'. This will help in practical application of this study's findings and bring the graduates closer to the construction industry needs and requirements. 


\section{References}

Aliakbarlou, S., Wilkinson, S., \& Costello, S. B. (2017a). Exploring construction client values and qualities: are these two distinct concepts in construction studies? Built Environment Project and Asset Management Journal, 7(3), 234-252.

Aliakbarlou, S., Wilkinson, S., Costello, S. B., \& Jang, H. (2017b). Achieving Postdisaster Reconstruction Success Based on Satisfactory Delivery of Client Values within Contractors' Services. Journal of Management in Engineering, 34(2), 04017058.

Aliakbarlou, S., Wilkinson, S., Costello, S. B., \& Jang, H. (2017c). Client values within post disaster reconstruction contracting services. Disaster Prevention and Management: An International Journal, 26(3), 348-360.

Aliakbarlou, S., Wilkinson, S., Costello, S. B., \& Jang, H. (2017d). Conceptual client value index for post disaster reconstruction contracting services. KSCE Journal of Civil Engineering, 22(4), 1067-1076. 10.1007/s12205-017-0432-1

Aliakbarlou, S., Wilkinson, S., \& Costello Seosamh, B. (2018). Rethinking client value within construction contracting services. International Journal of Managing Projects in Business, early citation. doi:10.1108/IJMPB-07-2017-0076

Becker, G. (1975). Human Capital: Chicago, IL: Chicago University Press.

Brynteson, R. (2012). Innovation at Work: 55 Activities to Spark Your Team's Creativity: Amacom Books.

Building and Economics Research Limited. (2003). Assessment of the Economic Impact of Efficiency Improvements in Building and Construction. Retrieved 1 Sep 2016, from http://www. branz.co.nz/cms_show_download.php?id=9355bd8b85c79bb5337bcfbe26c9952ae9f5e95b

Carroll, C. (2011). Accessing the graduate labour market: assessing the employability of Irish non-traditional graduates of Trinity College, Dublin. Widening Participation and Lifelong Learning, 13(2), 86-104.

Confederation of British Industry. (2009). Future fit: Preparing graduates for the world of work: CBI London.

Constructing Excellence. (2009). DBH Building \& Construction Taskforce: Procurement Working Group. Retrieved 1 Sep 2016, from http://www.constructing.co.nz/files/file/114/Report\%20 for\%20DBH\%20Procurement\%20Working\%20Group\%20220109\%20lssue\%201.0.pdf

Construction Strategy Group. (2015). The NZ Industry. Retrieved 1 March 2015, from http://www. constructionstrategygroup.org.nz/industry.php

Culkin, N., \& Mallick, S. (2011). Producing work-ready graduates: The role of the entrepreneurial university. International Journal of Market Research, 53(3), 347-368.

Egbelakin, T., Wilkinson, S., \& Ingham, J. (2015). Integrated framework for enhancing earthquake risk mitigation decisions. International journal of construction supply chain management, 5(2), 34-51.

Eurobarometer, F. (2010). Employers' perception of graduate employability. Available online: fl_304.

Finch, D. J., Hamilton, L. K., Baldwin, R., \& Zehner, M. (2013). An exploratory study of factors affecting undergraduate employability. Education+ Training, 55(7), 681-704. 
Hayward, C., \& Horvath, P. (2000). The effect of cooperative education on occupational beliefs. Journal of Cooperative Education, 35(1), 7.

Herrmann, K., Hannon, P., Cox, J., Ternouth, P., \& Crowley, T. (2008). Developing entrepreneurial graduates: putting entrepreneurship at the centre of higher education: NESTA London.

Johnson, D. W., Johnson, R. T., \& Smith, K. A. (2014). Cooperative learning: Improving university instruction by basing practice on validated theory. Journal on Excellence in University Teaching, 25(4), 1-26.

Lambert, R. (2003). Lambert review of business-university collaboration.

Mbachu, J., \& Nkado, R. (2004). Reducing building construction costs; the views of consultants and contractors. Paper presented at the Proceedings of the International Construction Research Conference of the Royal Institution of Chartered Surveyors, Leeds Metropolitan University.

New Zealand Ministry of Education. (2013). Looking at the employment outcomes of tertiary education. Retrieved 1 June 2018, from https://www.educationcounts.govt.nz/_data/assets/ pdf_file/0020/143561/Looking-at-the-employment-outcomes-of-tertiary-education-ii.pdf

PWC. (2016). Valuing the role of construction in the New Zealand economy. Retrieved 1 Sep 2016, from http://infrastructure.org.nz/resources/Documents/Reports/CSG\%20PwC\%20Value\%20 of\%20Construction\%20Sector_final\%20report_2016_10_16.pdf

Raidal, S. L., \& Volet, S. E. (2009). Preclinical students' predispositions towards social forms of instruction and self-directed learning: a challenge for the development of autonomous and collaborative learners. Higher Education, 57(5), 577-596.

Ray, R., Mitchell, C., \& Abel, A. L. (2012). The State of Human Capital 2012: False Summit: why the Human Capital Function Still Has Far to Go, Research Report No. R-1501-12-RR, McKinsey and Company.

Scager, K., Boonstra, J., Peeters, T., Vulperhorst, J., \& Wiegant, F. (2016). Collaborative learning in higher education: Evoking positive interdependence. CBE-Life Sciences Education, 15(4), ar69.

Sugar, W., \& Schwen, T. (1995). Glossary of technical terms. In L. e. Kelly (Ed.), ASTD Technical and Skills Training Handbook.: McGraw-Hill, New York.

Universities New Zealand. (2018). Growing New Zealand's economy. Retrieved 1 June 2018, from https://www.universitiesnz.ac.nz/sector-research/growing-new-zealand-economy 